\title{
O papel da mídia na divulgação e invenção de doenças
}

A interface entre a pesquisa e a sociedade está repleta de particularidades, as quais são tão diversas quanto os seres humanos em suas manifestações, intenções, necessidades e atitudes. Dentro do modo de produção capitalista, não é nada espantoso que os resultados de uma pesquisa ou o conhecimento inerente a um dado assunto gerem ou sejam utilizados para gerar riqueza. Um Estado desenvolvido teria que ser capaz, respaldado na cultura, tradições, organização social e principalmente seus cidadãos, de discernir o que é benéfico, correto e justo aos seus integrantes.

Recentemente Steven Woloshin e Lisa M Schwartz publicaram um artigo [PloS Med 2006; 3(4): e170] sobre o quanto a mídia contribui para a "fabricação" de doenças à população. Neste artigo os autores mencionam o papel da indústria e seu interesse econômico, mas fundamentalmente focam o quanto a mídia "desavisada" ou irresponsável pode contribuir para a divulgação de uma doença, sua gravidade e sua abrangência, alimentando a quase sempre fecunda imaginação do leitor.

O uso de informações que possam explicar particularidades de nossas vivências é invariavelmente realizado pelos seres humanos, independentemente de seu nível sócio-cultural, sendo mesmo uma característica de seu comportamento, onde a todo instante busca ordenar em seu mundo interno a infinidade de estímulos a que está submetido, e que pode ser bem compreendido, tanto em sua historicidade quanto significado, no conceito grego de pathos $(\pi \alpha \theta$ o $\sigma)$. Note-se que mesmo estudantes de medicina, tendem a se diagnosticar em conformidade com a aula a que estão sendo expostos, sendo muitas vezes tarefa dos preceptores demonstrar num infinito mundo de detalhes que aquela percepção particular que teve do assunto não é representativa de sua própria condição.

No citado artigo os autores apontam os principais elementos associados ao que poderia ser a invenção de doenças: 1) exagerar a prevalência das doenças, ou seja, a) criar uma ampla definição da doença, baseada em sintomas vagos e freqüentes, b) publicar uma elevada estimativa de prevalência. c) ofuscar a distinção entre formas leves e graves da doença, 2) estimular a realização de mais diagnósticos, d) destacar que os médicos falham em reconhecer a doença, e) encorajar as pessoas a se verem como doentes, f) promover campanha de alerta a doenças (semana de alerta a doença, clínicas de triagem, grupos de suporte, associações de doença), g) sugerir que todas as doenças devam ser tratadas, 3) exagerar os benefícios dos medicamentos a todos com a doença, h) sugerir que não há desvantagem em se tratar a doença, i) sugerir que o tratamento a longo prazo é seguro e efetivo.

O mais louvável neste artigo é, mais uma vez, a possibilidade de reflexão a que ele incita, pois muitas vezes já discutimos o quanto a mídia pode ser favorável ou não em relação à divulgação de doenças, dado que a linguagem e a tentativa jornalística de fazer um discurso técnico penetrar na densa massa heterogênea da audiência, invariavelmente permitirá deslizes conceituais e distorções de interpretações. É muito comum que os médicos entrevistados para determinadas matérias jornalísticas refiram que o texto apenas se aproxima daquilo que ele proferiu quando abordado, e mesmo as aspas que sugerem ser textual a citação, vem sempre dentro de um contexto que pode ser bem diferente. Dentro desta mesma preocupação com o que se divulga sobre saúde à população, muitos médicos costumam assistir a programas como o "Fantástico", pois sabem que nas semanas seguintes será visitado pelos pacientes para solver temores que foram avivados na matéria jornalística. É muito mais fácil à mídia divulgar conhecimentos das ciências básicas, mas quase impossível divulgar conhecimentos das ciências clínicas. A clínica ocupa um espaço probabilístico, multifatorial, pluridimensional que muito dista do senso comum, e pode ser hermética, em suas particularidades, até mesmo a alguns médicos.

Os autores discutem como a mídia coopera e como a mídia poderia evitar sua participação neste conceito de falsificação de doenças.

A síndrome das pernas inquietas é bastante real e impõe grande sofrimento aos portadores de suas formas graves. 0 diagnóstico é fundamentalmente clínico e o tratamento, quando indicado, pode ser muito efetivo, mas pode estar associado a piora dos sintomas. Não sabemos a prevalência da doença na população brasileira, e não há dúvida de que ainda é pouco conhecida dos médicos, e exatamente porque pode ser mal interpretada, também pode ser minimizada dentro da percepção médica, pois mover e balançar as pernas pode representar muitas coisas e a maioria delas não é doença.

A sugestão deste editor é que nossos leitores acessem o artigo de Steven Woloshin e Lisa M Schwartz e façam suas considerações, sendo importante lembrar que mesmo as mais renomadas revistas médicas em todo o mundo publicam pesquisas que podem ter indiscutíveis interesses econômicos. Mesmo a pesquisa dos autores supracitados foi realizada com base nas publicações que apareceram na mídia decorrentes de uma única campanha, a do ropinerole, que eles mesmos reconhecem como fraqueza da pesquisa. Cabe ao médico crítico e hábil, tanto no domínio dos instrumentos diagnósticos e de tratamento, ponderar sobre preceitos baseados nas melhores evidências disponíveis. Dominar conhecimentos de epidemiologia clínica, saber ler o material e método das pesquisas, é atividade obrigatória ao médico e aos formadores nas escolas médicas. A consideração maior dos autores é de que o jornalista seja prudente e difunda a informação para beneficiar e não para prejudicar a população, mesmo que histórias dramáticas sejam verídicas, é bem provável que sejam particulares, devendo-se sempre deixar claro outras versões do assunto.

Prof. Dr. Gilmar Fernandes do Prado Diretor do Laboratório de Sono Hospital São Paulo - UNIFESP 